DOI $10.31651 / 2524-2660-2020-4-17-24$

ORCID 0000-0003-4637-6604

MARTSIKHIV Khrystyna,

Ph.D in Pedagogy, Associate Professor, Foreign Languages Department, Lviv Polytechnic National University e-mail: khrystyna.hrytsko@gmail.com

УДК 378.018.8:070]:378.4(73)(045)

\title{
PECULIARITIES OF APPLYING VARIOUS APPROACHES TO THE PROFESSIONAL JOURNALISTS' TRAINING AT THE US UNIVERSITIES
}

Introduction. It is necessary to note that integration and globalization processes have considerably affected the training of future journalists, making new demands on the society. Due to these advances different approaches to the journalist's educational process started to be used by lecturers.
The purpose of the article is to analyze approaches introduced in the educational process of professional journalists' training.

The methods. To achieve a certain purpose, a set of research methods have been used: general scientific including analysis and synthesis have 
been applied for the investigation of legal documentation, instructional programs; induction and deduction have been used to highlight the features of professional journalists' training in US universities; due to methods of system-structural and systemfunctional analysis the main components of journalism education in the USA have been singled out.

Results. In the course of the research various approaches applied during the professional training of journalists in the USA have been characterized. Main peculiarities of axiological, acmeological, synergetic, hermeneutic, diagnostic, competencybased, andragogic, organizational, functionalsystematic, student-oriented, culturological and interdisciplinary approaches have been identified. Due to the freedom of the development of the society it has been investigated that these approaches have such similarities: integrated use of learning tools, methods and technologies; reasonable focus on forming professional qualities of future journalists.

The scientific originality of the results obtained is determined by the fact that for the first time thorough analysis of approaches used in the US educational system for the professional journalists' training has been conducted.

Conclusion. On the basis of the conducted research it is outlined that the professional journalists' training at the US universities is grounded on theoretical likewise practical approaches. Taking into consideration developed provisions, the organization of professional journalists' training, will contribute to the formation of highly qualified media specialists abled to compete in the labor market.

Keywords: the USA; university; educational system; approaches; professional training; journalist.

Formulation of the problem. Dynamic and rapid challenges of the XXI century, the development of new technologies, globalization processes that take place in the educational system, increasing competition among universities, practical knowledge put new demands on the training of future professionals in journalism, and necessitate applying different approaches to learning. Therefore, it becomes relevant to study mechanism and peculiarities of approaches applied during the professional journalists' training in the USA and also specify their impact on the future career prospects.

Brief overview of recent research and publications. The topic concerning peculiarities of applying various approaches to the professional journalists' training is of great importance and was analyzed by domestic and foreign scientists. Significant contribution to the analysis of introducing acmeological, axiological and culturological approaches to the journalists' training was done by such scholars A. Derkach, J. Hartley, A. Kiryakova, S. Kuzikova, G. Melekesov, T. Olkhovaya, A. Presnev.

The issues of competency-based and student-oriented approaches are concern of such modern scientists as M. Awward,
L. Filatova, R. Millrud, S. Vitvitska, A. Usacheva and others. Over the past decades studies related to the main features of system-functional and interdisciplinary approaches has been a matter of scientific research of V. Andriashun, K. Altmeppen, P. Hills, N. Voloshchuk, R. Walken.

The purpose of the article is to analyze approaches introduced in the educational process of professional journalists' training.

Results. In the United States, journalism is developing rapidly and dynamically and is constantly influenced by the needs of the modern labor market. As a result, media phenomena, trends and challenges are rethought, new requirements for professional training of journalists are put forward, programs are reviewed and updated, new special courses are offered, etc. That is why journalists need to improve their professional skills to meet the demands of employers, presenting competitiveness.

Professional training of journalists in the United States is carried out within colleges and universities, which need to know the needs of the modern media market and should focus on them, creating programs of specialized courses, but not subject only to their vision. Journalism faculties must work together with the media industry to make demands on education. Thus, if the media business contributes to the implementation of these requirements, positive changes will occur in the formation of the journalist's personality in the context of university education.

It is important to state that due to modern challenges, occupying all spheres of American life; a lot of transformations were introduced within the educational system. These changes, the development of up-to-date technologies, globalized processes; high level of competition among universities put new demands on the professional training of future journalists and necessitates the use of various approaches to learning.

Analyzing the peculiarities of the US higher educational system in accordance with the development of international trends, it has been found that the training of future journalists is based on a competency-based approach aimed at achieving high results.

Initially, in didactics the competencybased approach is characterized through the prism of its connection with the reorganization of content, the process of achieving goals and learning outcomes, based on the fact that "educational result is not only the acquisition of knowledge, skills and key competencies in intellectual, communicative, information, social spheres" [1, p. 271]. 
In Philadelphia, the Department of Education has introduced a "results-based system" focused on state-of-the-art education; creating a favorable academic, cultural, professional and social environment in accordance with knowledge and intelligence of students by involving them in mobility activities [2]. Thus, it is concluded that the formation of general and professional competencies of journalist students is the part of the educational outcomes, determined by the standards of professional education, and have a positive impact on the training of future professionals.

Taking into consideration the structural elements of professional competence of the journalist specialist, Zymnyaya identifies the following components: motivational aspect (readiness to demonstrate competence); cognitive (knowledge of competence content); behavioral (manifestation of competence in various standard and non-standard situations); semantic value (attitude to the content of competence and the object of its application); emotional and volitional regulation of the process and the result of the process of manifesting competence. The scientist considers competence as an organization of subject-specific knowledge that contributes to effective decision-making during professional activities. The researcher assures that knowledge must meet the following requirements: diversity (knowledge from different subject fields); structure; efficiency and accessibility; flexibility [3, p. 25-26].

According to Millrud, "competence" is considered as a potential opportunity for a future specialist to get a job in the labor market. The scientist identifies the following key competencies of the future specialist: literacy, computer experience (information technology skills), mastery of problem-solving skills, flexibility and adaptation to the innovation environment [4, p. 33].

Analyzing the features of the competencybased approach, Filatova considers the concept of "competence" as the ability to mobilize knowledge, skills, experience and behavior in specific situations; a combination of intelligence and skills [5].

Researching the professional training of future journalists in the USA, scholars consider the features of the student-oriented approach as the unity of individual psychological characteristics through the content and forms of learning aimed at selforganization, self-realization and self-control [6, p. 128]. It should be noted that the flexibility of instructional programs, the choice of educational trajectory are implemented in accordance with the preferences and interests of future journalists at the US universities.
According to Nichkalo special emphasis should be placed on the value of the provisions related to the student-oriented paradigm of modern education in the process of professional training. Such an approach will contribute to the spiritual development of the future specialist's personality, the formation of national consciousness, patriotism, a sense of professional honor and dignity, the ability to work in a production team. It is necessary to point out that student-oriented learning is the education organization process based on the comprehensive consideration of individual needs and capabilities of the student, deep respect for his personality, attitude to him as a conscious and responsible subject of educational interaction with teachers and peers. The purpose of this type of learning is to create conditions (content, methods, and environment) for individual self-realization of the student, selfdevelopment of his personal qualities $[7, \mathrm{p}$. 92].

It is significant to highlight that interdisciplinary approach plays the crucial role in the process of professional journalists' training. In the context of an interdisciplinary approach, types of instructional training programs for journalists at the US universities have been analyzed. The major program combines two disciplines from different fields. For example, the Computer Science and Journalism program at Northeastern University, College of Art, Media, and Design is based on learning the principles and responsibilities of a journalist, as well as understanding systems and technologies that support digital media.

Medill School of Journalism, Media, Integrated Marketing Communications at Northwestern University offers a dual specialization program, according to which students can study journalism and political science at the same time; journalism and international relations; journalism and social sciences; journalism and ethnography; journalism and foreign languages.

It is proved that interdisciplinary approach is based on integration methods, theories, knowledge of various disciplines used to implement innovative solutions in unknown problem situations [8]. Other scholars define interdisciplinary learning as an opportunity to gain knowledge about social, economic, political and cultural aspects of life in different countries. The interdisciplinary learning of future specialists in journalism stimulates the development of critical thinking, promotes new knowledge and teaches students to be open to different points of view [9]. 
Andriyashin considers interdisciplinary integration as a purposeful strengthening of interdisciplinary ties while preserving the theoretical and practical integrity of academic disciplines; systematization of knowledge and skills acquired by students from different disciplines [10]. It should be noted that the information learned during the study of disciplines should not be repeated, but only contribute to the motivation of students' learning activities, updating knowledge, skills and abilities.

Having studied the instructional training programs for future journalists at the US universities, the feasibility of interaction between journalism and political science has been considered. Would-be journalists studying this discipline will gain knowledge not only about the features and consequences of propaganda, but also about the political system of the United States and around the world; negative and positive impact of policy on the government functioning. As a result, journalist students, having got knowledge in the theory and practice of mass communication and political science will be able to offer a wide range of solutions to problems at the international level. Students who help organizations maintain relationships with foreign clients and partners gain theoretical knowledge about the norms, traditions and rituals of different countries, as well as the impact of social issues on the media.

Thus, future journalists can become more competent analysts by investigating world events, understanding the sociology of media organizations, as well as the mechanism of writing news. However, knowledge of methods how to write news creatively and insightfully is not enough, that is why journalist students must focus on the analysis of social and organizational issues.

The study of anthropology provides students with knowledge of how tribal societies shape thought; reasons for respect and contempt for different cultures, and offers practical advice on creating communication companies in profitable and non-profitable sectors with a global understanding of the man's essence.

The study of information technology is an important resource for journalist students, helps to master the latest technologies and use them in creating news, showing competitiveness in the labor market [11, p. 110-113].

Interaction problems of journalism with natural sciences, in particular geography, are of great interest to scientists. It is proved that the media is considered to be an act of communication that encompasses the processes by which information and facts from different geographical areas are collected. That is why journalism must be integrated with geography at the contextual and methodological levels.

The scientist Thorne examines the connection between journalism and geography, justifying the creation of media and geographical science. According to Thorne, visual literacy is a necessary skill for future journalists, which is based on the creation and destruction of images of a particular geographical area. The creation and interpretation of visual images is important for future professionals in the field of journalism, as well as geographers, which makes these sciences unique and interconnected [12, p. 787-790].

Summarizing the above information, it is said, that journalism has a high potential for interaction with both the humanitarian and political sciences. Interdisciplinary connections in the system of professional journalists' training are realized through integrated instructional programs.

In the context of organizational and functional-systematic approaches, which focus on the formation of social responsibility of higher education, professional training of journalists should promote the development of trust, honesty, truthfulness and intercultural communication; the ability to properly fulfill the social responsibilities of the media, defending the rights of their country [13, p. 56].

The culturological approach emphasizes that understanding cultural norms and culture in general is an important component of training journalists. This approach is implemented through the formation of professional competencies: future journalists learn how to explore textual relationships between producers (media and government organizations) and recipients (audience); encrypt and decipher historically important events in the cultural life of the country. It is noted that culture is one of the means of communication through which journalists can express their opinions. In turn, journalism is part of everyday culture, and as an industry it plays an important role in creating the meaning of the word; revealing hidden meanings, as well as the formation of thought, reflecting the cultural aspect of the country [14].

It is important to outline that the desire for global leadership have led to the emergence of the concept of "American internationalism", which focuses on human values and humanistic principles, provides freedom, favorable economic opportunities, cultural rights, human dignity and well-being . At the beginning of the XXI century, special attention is paid to the role of the university in the knowledge society. New technologies, globalization of the education market and increasing competition among universities, trans- 
formation of employment, priority and practical orientation of knowledge form the basis for implementing the leadership of faculty $[15$, p. 39].

In the context of comparative pedagogical research, axiological approach is thought to be one of the leading approaches to pedagogy, aimed at the humanistic development of the individual, revealing values as essential characteristics of the individual. According to this approach, each participant in the educational process is an active, valuemotivated subject of the activity [16, p. 162]. The use of the axiological approach made it possible to analyze the content of professional training programs for journalists at the US universities in order to form common and professional values.

Axiological focuses on the development of personal, moral and cultural qualities of future journalists. This approach in the training of journalism specialists is implemented through the formation of student personality values, which include academic freedom and mobility, solidarity, critical thinking, and based on self-determination, self-expression, professional mobility; values of civil society, namely freedom, openness, social justice, responsibility, tolerance, ethical norms [17, p. 24].

Civic education in the United States is viewed as a strategic direction of axiological approach and educational development that requires reorganization of the content of instructional programs, promoting the formation of political culture, interethnic relations, awareness of moral values, understanding of freedom and motivation to work. Civic education is based on multiculturalism, which aims to prepare citizens for life in a multinational environment.

Scholars substantiate the expediency of civic education in the process of professional training of future journalists, which is due to the basic principles of the media industry. The main direction of civic education of journalists at the US universities is the development of a culture of interethnic relations, based on the ability to tolerantly communicate with different ethnic cultures and show respect for them [18].

The development of the following moral values plays a ccrucial role in the civic education of journalist students: justice, honesty, trust, respect and responsibility. The basis of education is the formation of moral consciousness, behavior; beliefs and feelings, etc. According to Darendorf "the main task of civic education of future journalists is to ensure an understanding of freedom in all its manifestations, as well as the opportunity to be free from social roles" [19, p. 62].
Preparing future journalists for continuous professional activity is impossible without the formation of personal and professional values, which are the basis of the content of professional education and contribute to personal self-development.

According to Garanina the set of personal and professional values determines the process of personal self-development, influencing its dynamism, and is the central mechanism at all stages of personal and professional development [20].

Summarizing the above information, it is outlined that the use of axiological approach in the training of future journalists will contribute to the formation of values and continuity of professional self-development, their awareness of their self-worth in today's information society, understanding how to build a professional career, achieve goals.

In the context of studying the theoretical foundations of professional journalists' training at the US universities, acmeology considers the possibility of students to achieve the peaks of creative and personal development, the ability to self-improvement, etc. According to Kuzikova, acmeology aims to identify hidden, unrealized opportunities, taking into account the ratio of potential and actual personality development [21].

Researching the professional training of future journalists from the perspective of the acmeological approach it is essential to consider the self-development of students as a tendency to self-revealing of creative potential; conscious process of self-improvement for the purpose of effective self-realization, taking into consideration external and internal influences of society; spiritual-moral and practical self-enrichment. Taking into account the above information, it is worth emphasizing the opinion that self-development is a purposeful process of "deployment" of existing but "folded" abilities, skills, qualities or "origin" and formation of properties and qualities have not existed before.

As it is noted, the modern information society and market economy conditions in the United States make new demands on professionals. It is important to emphasize that computers and information technology are designed and improved to help people think, work and learn effectively. They not only expand professional opportunities, but also require deepening of knowledge, improvement of experience in the process of continuous professional development [22, p. 29].

In particular, the profession of a journalist has been significantly influenced due to the need to master the latest media technologies. Thus, the need to use the andragogic approach is actualized. Lukyanova argues that 
the education that students receive in higher education institutions cannot fully meet the needs of the individual and the labor market that is why the urgent problem is to find an updating content. One of the best ways to solve this problem is to introduce continuous adult learning that is thought to be an integrative element of personal life, a condition for the constant development of individual experience in the process of socialization [23].

The synergetic approach in the context of professional journalists' training in the US university education system is implemented through the use of a wide range of different learning technologies: project method, "brainstorming", discussion, research, business etc. Synergetic approach is an interdisciplinary approach in education, based on nonlinearity (development in different directions), openness (taking into account external changes and new challenges of time) and coherence (coherence of development directions to mutually reinforce them), a new methodology that provides personality freedom in the learning process [24, p. 10].

The hermeneutic approach to professional training in journalism is associated with the development of intellectual abilities that help to understand, interpret speech signs, as well as correctly express their thoughts orally or in writing [25].

The diagnostic approach in the learning process helps journalists to navigate the flow of information; work with its different types; find and select the necessary material; critically analyze, classify and generalize it [26].

Conclusions. To conclude, it is necessary to emphasize that professional training of journalists is realized in the conditions of university education of the USA, taking into account tendencies of the international educational space, in particular globalization, internationalization and transnationalization.

It was found that the professional journalists' training in higher education institutions of the USA is based on student-oriented, hermeneutic, andragogic, diagnostic, acmeological, axiological, culturological, competency-based and synergetic approaches.

Prospects for further scientific research. Wide spectrum of approaches in the US higher establishments is found to be useful in the process of introducing them into the educational process of Ukrainian universities.

\section{References}

1. Palamar, S.P. (2018). Competence approach as a methodological guideline for the modernization of modern education. Educational Discourse, 1-2(2021), 267-278.
2. Awward, M. (2012). Outcomes-based education and employability at Philadelphia University. International journal of humanities and social sciences, 2(10), 111-121.

3. Zimnyaya, I.A. (2004) Key competencies as a resultbased basis of the competency approach in education. Moscow: Research Center for Quality Training (in Rus.).

4. Milrud, R.P. (2004). Competence in language learning. Foreign languages in school, 7, 30-37.

5. Filatova, L.O. (2004). Continuity of general secondary and university education. Pedagogy, 8, 63-68.

6. Kortokova, L.I. (2016). Methodological approaches to professional training of future specialists in the field of services in the educational and industrial cluster. Scientific Bulletin of Melitopol State Pedagogical University. Series: Pedagogy, 2, 126-130.

7. Nichkalo, N.G. (2008). Transformation of vocational education in Ukraine. Kyiv: Pedagogical thought (in Ukr.).

8. Lam, J.C.K., Walker, R.M., Hills, P. (2014). Interdisciplinarity in Sustainability Studies: A Review. Sustainable Development, 22(3),158-176.

9. Gantogtokh, O., \& Quinlan, K.M. (2017). Challenges of designing interdisciplinary postgraduate curricula: case studies of interdisciplinary master's programmes at a research-intensive UK university. Teaching in Higher Education, 22(5), 569-586.

10. Andriyashin, V.I \& Karachun, L.V (2010). Ensuring continuity through interdisciplinary links. Scientific journal of the National Pedagogical University M.P. Dragomanov, 13(6), 9-13.

11. Petrausch, R.J. (2008). Five Strategic Imperatives for Interdisciplinary Study in Mass Communications/Media Studies in the US and UK. Interdisciplinary Learning and Teaching in Higher Education: Theory and Practice, 124

12. Thorne, J. (2004). The visual turn in geography. Antipode, 36(5), 787-794.

13. Altmeppen, K. D. (2008). The structure of news production: The organizational approach to journalism research. In: Global journalism research: theories, methods, findings, future, 52-64.

14. Hartley, J. (2008). Journalism as a human right: The cultural approach to journalism. In: Global journalism research: Theories, methods, findings, future, 39-51.

15. Mukan, N., Havrylyuk, M., \& Stolyarchuk, L. (2015). Theoretical Framework of Leadership in Higher Education of England and Wales. Comparative Professional Pedagogy, 5(1), 39-45.

16. Fritsyuk, V.A. (2017). Methodological approaches to studying the problem of professional selfdevelopment of the future specialist. Bulletin of Vinnytsia Polytechnic Institute, 6, 160-167.

17. Kiryakova, A.V., Olkhovaya, T.A., Melekesov, G.A., $\&$ Presnov, A.A. (2015). The axiological approach to the analysis of the problems of modern university education. Mediterranean Journal of Social Sciences, 6(2), 22.

18. Likhnevskaya, T.A (2009). Civic education of student youth in US high school. Thesis of Ph.D dissertation. Ternopil: Ternopil National Pedagogical University named after V. Hnatiuk.

19. Darendorf, R. (1989). After 1989. Morality, revolution and civil society. Reflections on the revolution in Europe. Moscow: Ad Marginem (in Rus.).

20. Garanina, J.G. (2013). Psychological competence in the structure of personal and professional selfdevelopment of specialists in the socionomic sphere. Saransk: Mordov Publishing House (in Rus.).

21. Kuzikova, S.B. (2013). Self-development of personality: a subjective approach. Personality Psychology, 1, 77-86.

22. Mukan, N., Noskova, M., \& Baibakova, I. (2017). The formation of school principals' readiness to use internet technologies in their work in the system of 
continuous pedagogical education. Science and $\mathrm{Ed}$ ucation, 4, 123-132.

23. Lukyanova, L.B. (2012). Andragogic experience in organizing vocational training in the workplace. Modern information technologies and innovative teaching methods in training: methodology, theory, experience, problems, 1(29), 86-90.

24. Bech, I.D. (2003). Education of personality: in 2 books. Book 1: Personality-oriented approach: theoretical and technological principles. Kyiv: Lybid. (in Ukr.)

25. Onishchenko, V.D. (2002). Pedagogical hermeneutics: noological contexts of identification. Pedagogy and Psychology of Vocational Education, 2, 23-31.

26. Galuzyak, V.M. (2018). Pedagogical diagnostics as a system. Vinnytsia: Nilan-LTD LLC. (in Ukr.)

\section{Список бібліографічних посияань}

1. Паламар, С.П. Компетентнісний підхід як методомогічний орієнтир модернізації сучасної освіти. Освітологічний дискурс, 2018. Т. 1-2. Ч. 20-21. C. 267-278.

2. Awward M. Outcomes-based education and employability at Philadelphia University. International journal of humanities and social sciences, 2012. 2(10). P. 111-121.

3. Зимняя И.А. КАючевые компетентности как результативно-целевая основа компетентностного подхода в образовании. Москва: Исследовательский центр проблем качества подготовки специаАистов, 2004. С. 20.

4. Мимьруд Р.П. Компетентность в изучении языка. Иностранные языки в школе, 2004. №7. С. 30-37.

5. Филатова М.О. Преемственность общего среднего и вузовского образования. Педагогика, 2004. №8. C. 63-68.

6. Кортокова М.I. Методологічні підходи до професійної підготовки майбутніх фахівців сфери посцуг в умовах освітньо-виробничого кластеру. $\mathrm{Ha}$ уковий вісник Мелітопольського державного педагогічного університету. Серія: Педагогіка, 2016. №2. C.126-130.

7. Ничкало Н.Г. Трансформація професійнотехнічної освіти України. Київ: Педагогічна думка, 2008. 156 с.

8. Lam J.C.K., Walker R.M., Hills P. (2014). Interdisciplinary in Sustainability Studies: A Review. Sustainable Development, 2014. № 22. P.158-176.

9. Gantogtokh O., \& Quinlan K.M. (2017). Challenges of designing interdisciplinary postgraduate curricula: case studies of interdisciplinary master's programs at a research-intensive UK university. Teaching in Higher Education, 2017. № 22. P. 569-586.

10. Андріяшин B.I. \& Карачун К.В. (2010). Забезпечення наступності засобами міжпредметних зв’язків. Науковий часопис начіонального педагогічного університету ім. М. П. Драгоманова, 2010. Cep. 13. 6. C. 9-13.

11. Petrausch R.J. Five Strategic Imperatives for Interdisciplinary Study in Mass Communications/Media Studies in the US and UK. Interdisciplinary Learn- ing and Teaching in Higher Education: Theory and Practice, 2008. $124 \mathrm{p}$.

12. Thorne J. The visual turn in geography. Antipode, 2004. 36(5). P. 787-794.

13. Altmeppen K.D. The structure of news production: The organizational approach to journalism research. In: Global journalism research: theories, methods, findings, future, 2008. P. $52-64$.

14. Hartley J. Journalism as a human right: The cultural approach to journalism. In: Global journalism research: Theories, methods, findings, future. New Jersey, USA: Blackwell Publishing, 2008. P. 39-51.

15. Mukan N., Havrylyuk M. \& Stolyarchuk, L. Theoretical Framework of Leadership in Higher Education of England and Wales. Comparative Professional Pedagogy, 2015. № 5. P. 39-45.

16. Фрицюк В.А. Методомогічні підходи до вивчення проблеми професійного саморозвитку майбутнього фахівця. Вісник Вінницького політехнічного інcmumymy, 2017. № 5. 6. C. 160-167.

17. Kiryakova A.V., Olkhovaya T.A., Melekesov G.A., \& Presnov A.A. The axiological approach to the analysis of the problems of modern university education. Mediterranean Journal of Social Sciences, 2015. № 6. $22 \mathrm{p}$.

18. Міхневська Т.А. Громадянське виховання учнівської молоді в середній школі США: автореф. дис. ... канд. пед. наук: спец. 13.00.01. Тернопімь: Тернопільський національний педагогічний університет ім. В. Гнатюка, 2009. 19 с.

19. Дарендорф Р. После 1989. Мораль, революция и гражданское общество. Размышиение о революции в Европе. Москва, 1989. Вип.12. 271 с.

20. Гаранина Ж.Г. Психологическая компетентность в структуре Аичностно-профессионального саморазвития специалистов социономической сферы. Саранск, 2013. 136 с.

21. Кузікова С.Б. Саморозвиток особистості: суб'єктний підхід. Психологія особистості, 2013. № 1. C. $77-86$

22. Mukan N., Noskova M., \& Baibakova I. The formation of school principals' readiness to use internet technologies in their work in the system of continuous pedagogical education. Science and Education, 2017. № 4. P. 123-132.

23. Кук'янова, К.Б. Андрагогічний досвід організаціі професійного навчання на виробництві. Сучасні інформаиійні технології та інноваційні методики навчання у підготовиі фахівиів: методологія, теорія, досвід, проблеми, 2012. № 1. С.86-90.

24. Бех І.Д. Виховання особистості: у 2-х кн. Кн. 1. Особистісно орієнтований підхід: теоретикотехнологічні засади. Київ, Аибідь, 2003. 280 С.

25. Онищенко В.Д. Педагогічна герменевтика: ноологічні контексти ідентифікації. Педагогіка і психологія профресійної освіти, 2002. № 2. С. 23-31.

26. Галузяк В.М. Педагогічна діагностика як система. Вінниця, Україна: Нілан- $\Lambda$ ТД, 2018. 155 с.

\section{МАРЦІХІв Христина Романівна,}

кандидатка педагогічних наук, доцентка кафедри іноземних мов,

Національний університет " $ь$ ьвівська політехніка"

\section{ОСОБАИВОСТІ ЗАСТОСУВАННЯ РІЗНИХ ПІДХОДІВ ДО ПРОФЕСІЙНОЇ ПІДГОТОВКИ ЖКУРНААICТIВ В УНВЕРСИТЕТАХ США}

Анотаиія. Проаналізовано особливості формування професійного розвитку майбутніх журналістів в умовах глобалізаиійних та інтеграиійних проиесах. Доведено, шо профресійна підготовка журналістів $\epsilon$ складним процесом та вимагае застосування різних nidxodis.

Виокремлено такі підходи у проиесі професійноі підготовки фахівиів із журналістики: компетентнісний, міждисииплінарний, культурологічний, аксіологічний, організаиійний, функиіонально-системний, акмеологічний, особистісно-орієнтований, діагностичний, синергетичний, герменевтичний, андрагогічний.

Охарактеризовано особливості застосування підходів до профресійної підготовки журналістів в університетах США. Встановлено, що аксіологічний підхід $\epsilon$ одним з провідних підходів, який застосовуеться у проиесі підготовки майбутніх медіа фрахівиів та спрямований на формування професійних иінностей.

Досліджено, шо у відповідності з розвитком міжнародних тендениій вищої освіти професійна підгото- 
вка майбутніх журналістів здійснюеться на основі компетентнісного підходу. Зазначено, що профресійна підготовка медіа фахівиів базується на застосуванні особистісно-оріентованого підходу, який спрямований на самооранізацію, самореалізацію та самоконтроль особистості. Обтрунтовано, шо в умовах сучасного розвитку суспільства чільне місие у процесі професійної підготовки займає міждисииплінарний підхід, в основі якого є вивчення журналістики у поєднанні з іншими предметними галузями.

Доведено, шо культурологічний підхід спрямований на розуміння культурних норм та культури у иілому, шо є важливою складовою навчання журналістів. Проаналізовано, що акмеологічний підхід зосереджується на формуванні таких иінностей майбутніх фахівиів з журналістики, а саме свободи слова, солідарності, мобільності та критичного мислення. У контексті організаиійного та функиіональносистемного підходів, які зосереджуються на формуванні соціальної відповідальності здобувача вищої освіти, досліджено, що професійна підготовка майбу тніх журналістів повинна фокусуватися на розвиткові чесності, правдивості, довіри, а також вмінню виконувати свої обов'язки згідно з нормами та правилами ЗМI.

Виявлено особливості синергетичного, діагностичного, андрагогічного та герменевтичного підходів. З'ясовано, шо усі підходи, які застосовуються до професійної підготовки журналістів, розглядаються як взаємозалежними та взаємодоповнюючими складовими професійної діяльності майбутніх медіа фахівuis.

ключові слова: США; університет; освітня система; підходи; професійна підготовка; журналіст.

Одержано редакиією 17.12.2020 Прийнято до публікаиї̈ 21.12.2020 